\title{
Antioxidant capacity and chemical composition in seeds rich in omega-3: chia, flax, and perilla
}

Sheisa Cyléia SARGI ${ }^{1}$, Beatriz Costa SILVA ${ }^{1}$, Hevelyse Munise Celestino SANTOS ${ }^{1}$, Paula Fernandes MONTANHER ${ }^{1}$, Joana Schuelter BOEING ${ }^{1}$, Oscar Oliveira SANTOS JÚNIOR ${ }^{1 \star}$, Nilson Evelázio SOUZA², Jesuí Vergílio VISENTAINER ${ }^{1}$

\begin{abstract}
The chemical composition and antioxidant capacity of five seeds, chia, golden flax, brown flax, white perilla, and brown perilla, were determined. The chemical properties analyzed included moisture, ash, crude protein, carbohydrates, total lipids, fatty acids, and antioxidant capacity $\left(\mathrm{ABTS}^{\circ+}, \mathrm{DPPH}^{\bullet}\right.$, and FRAP). The results showed the highest amounts of protein and total lipids in brown and white perilla. Perilla and chia showed higher amounts of alpha-linolenic fatty acid than those of flaxseed varieties, ranging between $531.44 \mathrm{mg} \mathrm{g}^{-1}$ of lipids in brown perilla, $539.07 \mathrm{mg} \mathrm{g}^{-1}$ of lipids in white perilla, and $544.85 \mathrm{mg} \mathrm{g}^{-1}$ of lipis in chia seed. The antioxidant capacity of the seeds, evaluated with ABTS ${ }^{\bullet+}$, DPPH ${ }^{\bullet}$, and FRAP methods, showed that brown perilla had greater antioxidant capacity when compared with white perilla, flax, and chia seeds.
\end{abstract}

Keywords: antioxidant capacity; chia; omega-3; Salvia hispânica; Perilla frutescens; Linum usitatissimum.

\section{Introduction}

Studies have shown a relationship between a highly nutritious diet, good health, and a reduced risk of chronic diseases (KENDALL et al., 2008). As a result, the investigation of functional foods has gained prominence for promoting beneficial effects to health (ANJO, 2004). Due to the growing interest in nutrition, it has gotten a major boost (NIVA; MÄKELÄ, 2007).

Among functional foods, chia, flax, and perilla are recognized as major vegetal sources of essential omega-3 (n-3) fatty acids, which are important to human health (ASIF, 2011), in addition to various nutrients such as proteins, fibers, and phenolic compounds (GALVÃO et al., 2008).

Chia (Salvia hispanica L., family Labiatae) is native to southern Mexico and northern Guatemala (ÁLVAREZCHÁVES et al., 2008). Some seeds are good sources of protein (19-23\%), with a higher content than those of other traditional crops such as wheat, corn, rice, oat, barley, and amaranth (COATES; AYERZA, 1996). The chia seed oil-extraction residual meal is a good source of dietary fiber and phenolic compounds with antioxidant capacity (REYES-CAUDILLO; TECANTE; VALDIVIA-LÓPEZ, 2008). Chia seeds contain about $25-38 \%$ oil and have the highest known percentage of alpha-linolenic fatty acid (LNA, 18:3n-3), approximately $60 \%$ (IXTAINA; NOLASCO; TOMÁS, 2008).

Perilla (Perilla frutescens, family Lamiaceae) is a plant native to Asian countries and is used in cooking and in traditional medicine; however, it remains unknown to western populations (KUROWSKA et al., 2003). Perilla seeds contain approximately $35-45 \%$ oil, and it is a good source of polyunsaturated fatty acids (PUFAs), especially LNA (54\%-64\%). Perilla leaves are used as a source of antioxidants (MENG et al., 2009). Moreover, perilla is known to have anti-bacterial, anticarcinogenic, antiseptic, antipyretic and anti-asthmatic properties, as well as immunomodulatory action (ŽEKONIS et al., 2008).

Flax (Linum usitatissimum, family Linaceae) is cultivated in more than 50 countries; however, Canada is its major producer (KASOTE; BADHE; HEDGE, 2013; RUBILAR et al., 2010). Nowadays, flax seed plays a major role in the field of diet and disease research because of its benefits to health and disease prevention properties (HERCI et al., 2011). The main component of flax seed is oil (36-40\%); Flax seed oil's major constituent is LNA (57\%) (GHULE; JADHAV; BODHANKAR, 2012; KASOTE; BADHE; HEDGE, 2013). Flax seed is an important source of fiber and protein, $30 \%$ and $20 \%$, respectively (OMAR et al., 2010) and is rich in phenolic compounds, known as lignans, responsible for its antioxidant activities (RUBILAR et al., 2010). Furthermore, flax seed has been associated with improving the nutritional value by increasing the concentration of omega-3 fatty acids in different animals and foods, fish (TONIAL et al., 2009; AGUIAR et al., 2007), ruminant (RUIZ et al., 2005; DUCATTI et al., 2009), and dairy goat (MATSUSHITA et al., 2007).

There has been a growing interest in the use of chia, perilla, and flax seeds in the diet since these oilseeds have become more popular functional food because of their reported benefits in cardiovascular diseases, cancer, neurological, and hormonal disorders and also for their antioxidant activities. Due to the high intake of these oilseeds and the fact that there are few studies in the literature on their composition and antioxidant capacity, the aim of this study was to characterize the chemical composition, antioxidant capacity, and fatty acid composition of chia, perilla, and flax seeds.

${ }^{1}$ Department of Chemistry, State University of Maringá - UEM, Av. Colombo, 5790, CEP 87020-900, Maringá, PR, Brazil, e-mail: oliveirasantos.oscardeoliveira@gmail.com

${ }^{2}$ Department of Food Technology, Federal Technology University of Parana - UTFPR, CEP 86036-370, Londrina, PR, Brazil

${ }^{*}$ Corresponding author 


\section{Materials and methods}

\subsection{Chemicals}

The reagents used were 2,2-diphenyl-1- picrylhydrazyl $\left(\mathrm{DPPH}^{\bullet}\right), 2,2^{\prime}$-azino-bis(3-ethylbenzthiazoline-6-sulphonic acid) (ABTS), 6-hydroxy-2,5,7,8-tetramethyl chroman-2carboxylic acid (Trolox), cellulose (spruce powder), 2,4,6-tris(2pyridyl)-s-triazine (TPTZ), and methyl tricosanoate (23:0) from Sigma Chemical. Potassium persulfate from Neon, ferrous sulphate from Vetec, and sodium carbonate from J.T Baker were also used.

\subsection{Samples}

Chia, brown perilla, white perilla, golden flax, and brown flax seeds were obtained from local producers in southern Brazil. The seeds were triturated (50 mesh), homogenized, and packaged in polypropylene bags and stored at $5^{\circ} \mathrm{C}$ until further analysis.

\subsection{Proximate composition and chromatographic analysis}

Moisture, ash, and protein contents were determined in accordance with AOAC (ASSOCIATION..., 1998). Total lipids were extracted with the Bligh and Dyer (1959) method.

Fatty acid methyl esters (FAME) were prepared by methylation of total lipids as described by Hartman and Lago (1973). Methyl esters were separated by gas chromatography in Thermo model trace ultra 3300 equipped with flame ionization and cyanopropyl capillary column $100 \mathrm{~m}$ x 0.25 i.d., $0.25 \mu \mathrm{m}$ film thickness, CP-7420 (MARTIN et al., 2008). The gas flow rates used were $1.2 \mathrm{~mL} \mathrm{~min}^{-1}$ carrier gas $\left(\mathrm{H}_{2}\right) ; 30 \mathrm{~mL} \mathrm{~min}^{-1}$ make-up gas $\left(\mathrm{N}_{2}\right) ; 35$ and $350 \mathrm{~mL} \mathrm{~min}^{-1}$ flame gases $\left(\mathrm{H}_{2}\right.$ and synthetic air, respectively). The sample splitting rate was $1: 80$, and the samples $(2 \mu \mathrm{L})$ were injected in triplicate. The operation parameters were as follows: detector and injection port temperature $240^{\circ} \mathrm{C}$, column temperature $185^{\circ} \mathrm{C}$ for 7.5 minutes, programmed to increase at $4^{\circ} \mathrm{C} \min ^{-1}$ to $235^{\circ} \mathrm{C}$ and kept at this temperature for 1.5 minutes. The peak areas were determined by ChromQuest 5.0 Software. For the fatty acid identification, retention times were compared with those of standard methyl esters.

Quantification (in $\mathrm{mg}$ fatty acid $\mathrm{g}^{-1}$ of total lipids) was made against tricosanoic acid methyl ester as an internal standard (23:0), as described by Joseph and Ackman (1992). Theoretical FID (flame ionization detector) correction factor (VISENTAINER, 2012) values were used to obtain fatty acid concentration values. Fatty acid contents were calculated in $\mathrm{mg} \mathrm{g}^{-1}$ of total lipids by using Equation 1 .

$F A=\frac{A_{X} W_{I S} C F_{X}}{A_{I S} W_{X} C F_{A E}} \times 100$

where FA is mg of fatty acids per $g$ of total lipids, $A_{x}$ is the peak area (fatty acids), $A_{I S}$ is the peak area of internal standard (IS) tricosanoic acid methyl ester (23:0), $\mathrm{W}_{\text {IS }}$ is the IS weight ( $\mathrm{mg}$ ) added to the sample (in $\mathrm{mg}$ ), $\mathrm{W}_{\mathrm{X}}$ is the sample weight (in $\mathrm{mg}$ ), $\mathrm{CF}_{\mathrm{X}}$ is the theoretical correction factor, and $\mathrm{CF}_{\mathrm{AE}}$ is the conversion factor necessary to express the results as mg of fatty acids rather than methyl esters.

\subsection{Analysis of antioxidant capacity}

In this study, the QUENCHER procedure was used to measure the total antioxidant capacity (TAC) using three well-known assays, $\mathrm{ABTS}^{-+}$, $\mathrm{DPPH}^{*}$ and FRAP and an UV-Vis spectrophotometer of Thermo Scientific brand, model Genesys 10uv (SERPEN; GÖKMEN; FOGLIANO, 2012a).

Dilution 1:1 (m/m) of chia, brown and white perilla samples with cellulose was necessary for the FRAP assay. For the ABTS •+ assay, all samples needed to be diluted at 1:1 (m/m), while no dilution was necessary for the DPPH• assay.

\section{Preparation of $A B T S^{\bullet+}, D P P H \cdot$ and FRAP radical solutions}

The ABTS solution was prepared by adding $5 \mathrm{~mL}$ of deionized water to $38.41 \mathrm{mg}$ of ABTS. A potassium persulfate solution was prepared by mixing $5 \mathrm{~mL}$ of deionized water with $6.615 \mathrm{mg}$ potassium persulfate. A total of $10 \mathrm{~mL}$ of stock solution of $\mathrm{ABTS}^{\cdot+}$ was prepared by reacting $5 \mathrm{~mL}$ of each solution described above, which resulted in final concentrations of $7 \mathrm{mmol} \mathrm{L}^{-1} \mathrm{ABTS}^{\bullet+}$ and $2.45 \mathrm{mmol} \mathrm{L}^{-1}$ potassium persulfate. The $\mathrm{ABTS}^{\bullet+}$ stock solution was allowed to stand in the dark at room temperature for $12-16 \mathrm{~h}$ before use (RE et al., 1999). The working solution of $\mathrm{ABTS}^{\bullet+}$ was prepared daily by diluting $10 \mathrm{~mL}$ of $\mathrm{ABTS}^{\cdot+}$ stock solution with approximately $800 \mathrm{~mL}$ of a water/ ethanol $(50: 50, \mathrm{v} / \mathrm{v})$ mixture. The working solution absorbance was $0.75-0.80$ at $734 \mathrm{~nm}$.

The DPPH• stock solution was prepared daily by dissolving $40 \mathrm{mg}$ of $\mathrm{DPPH}^{\bullet}$ in $100 \mathrm{~mL}$ of ethanol. This ethanolic solution of $\mathrm{DPPH} \cdot$ was further diluted with $100 \mathrm{~mL}$ of deionized water to obtain a $\mathrm{DPPH} \cdot$ stock solution in a methanol/water mixture $(50: 50, \mathrm{v} / \mathrm{v})$. The $\mathrm{DPPH}^{\bullet}$ working solution was prepared by diluting $200 \mathrm{~mL}$ of stock $\mathrm{DPPH}^{\bullet}$ solution with approximately $800 \mathrm{~mL}$ of a water/ethanol (50:50, v/v) mixture (BRANDWILLIAMS; CUVELIER; BERSET, 1995); its absorbance was $0.75-0.80$ at $525 \mathrm{~nm}$.

The FRAP solution was prepared by diluting an aqueous solution of $10 \mathrm{mmol} \mathrm{L}^{-1} \mathrm{TPTZ}$ and $20 \mathrm{mmol} \mathrm{L}^{-1}$ ferric chloride in $300 \mathrm{mmol} \mathrm{L}^{-1}$ sodium acetate buffer $(\mathrm{pH} 3.6)$ at a ratio of 1:1:10 (v:v:v), as described by Benzie and Strain (1996).

\section{Antioxidant capacity measurement by the QUENCHER procedure}

Powdered samples (50 mesh) $10 \pm 1.0 \mathrm{mg}$ were weighed in $15-\mathrm{mL}$ centrifuge tubes. Reaction was started by adding $10 \mathrm{~mL}^{-}$of either $\mathrm{ABTS}^{\bullet+}$ or $\mathrm{DPPH}^{\bullet}$ or FRAP working solutions to the tubes containing the powdered samples. The tubes were shaken rigorously for $60 \mathrm{~min}$ on an orbital shaker Fisaton model 752 in the dark at room temperature. After exactly $60 \mathrm{~min}$, the tubes were centrifuged at $9200 \mathrm{~g}$ for $2 \mathrm{~min}$ in a refrigerated centrifuge of Sanyo harier 18/80 model. Optically clear supernatants were transferred to corvettes and absorbance was measured at $734 \mathrm{~nm}, 525 \mathrm{~nm}$, and $593 \mathrm{~nm}$ for the ABTS•+, $\mathrm{DPPH}^{*}$ or FRAP assays, respectively. Standard calibration curves were constructed by plotting percentage quenching against the concentration of Trolox at $734 \mathrm{~nm}$ and $525 \mathrm{~nm}$ for the $\mathrm{ABTS}^{\bullet+}$ and $\mathrm{DPPH}{ }^{\bullet}$ assays, respectively. In the FRAP assay, the calibration curve was constructed by plotting color 
formation at $593 \mathrm{~nm}$ against the Trolox concentration. The antioxidant capacity of the samples determined through the $\mathrm{ABTS}^{*}$, DPPH ${ }^{*}$ and FRAP assays was calculated in $\mathrm{mmol}$ of Trolox equivalent antioxidant capacity (TEAC) per g of sample (SERPEN; GÖKMEN; FOGLIANO, 2012b).

\subsection{Statistical analysis}

All analyses were carried out in triplicate. The results were submitted to variance (ANOVA) analysis and Tukey's test at 5\% probability using Statistica 5.0 software (STATSOFT, 1995) and to Principal Components Analysis (PCA) using Statistica 7.0 software; data pre-treatment was unnecessary.

\section{Results and discussion}

\subsection{Proximate composition and chromatographic analysis}

The proximate compositions of the seeds analyzed are shown in Table 1. All seeds had low moisture content $(6.02 \%$ to $7.86 \%$ ), and no significant difference was found among the varieties of flaxseeds (golden and brown). Chia seeds showed the highest moisture and ash contents (7.86 and 3.63\%) and were statistically different $(\mathrm{p}<0.05)$ from the other seeds analyzed.
No significant difference was observed between the flaxseed varieties (golden and brown) and perilla (white and brown) regarding total lipid content, Peiretti et al. (2011) found lipid contents similar to those found in the present study, $42.10 \%$ and $43.00 \%$, respectively. On the other hand, chia seeds had the lowest amount of lipids (21.69\%), being statistically different from the other samples $(\mathrm{p}<0.05)$. A study on seed lipids found values of $44.80 \%, 40.00 \%$ and $35.00 \%$ for flax, chia, and perilla seeds, respectively (CIFTCI; ROMAN; RUDZINSKA, 2012).

All seeds analyzed contain a high protein value, above $20 \%$. However, brown perilla showed the highest protein content (25.38\%) and chia had the lowest content (21.52\%). Similar results were found for chia seed proteins by OlivosLugo,Valdivia-López and Tecante (2010), 24.60\% of the total weight. However, chia seed had the highest carbohydrate fraction $(45.30 \%)$, differing from the other samples tested $(\mathrm{p}<0.05)$. This is due to the high amount of dietary fiber contained in chia seed (MUÑOZ et al., 2012; VÁZQUEZOVANDO et al., 2009). The carbohydrate contents of flaxseed (brown and gold) and perilla (white and brown) varieties were similar, with no significant difference $(\mathrm{p}<0.05)$.

The fatty acid composition of the investigated oilseeds (Table 2) demonstrates that they are excellent sources of alpha-

Table 1. Proximate composition (\%) of chia, flax, and perilla seeds ${ }^{\mathrm{a}}$.

\begin{tabular}{lrrrrr}
\hline \multicolumn{1}{c}{ Component } & \multicolumn{1}{c}{ Chia } & Golden Flax & Brown Flax & White Perilla & Brown Perilla \\
\hline Moisture & $7.86^{\mathrm{a}} \pm 0.22$ & $6.73^{\mathrm{b}} \pm 0.03$ & $6.52^{\mathrm{bc}} \pm 0.04$ & $6.40^{\mathrm{c}} \pm 0.06$ & $6.02^{\mathrm{d}} \pm 0.12$ \\
Ash & $3.63^{\mathrm{a}} \pm 0.01$ & $2.84^{\mathrm{c}} \pm 0.01$ & $2.63^{\mathrm{d}} \pm 0.01$ & $3.33^{\mathrm{b}} \pm 0.03$ & $3.33^{\mathrm{b}} \pm 0.02$ \\
Total lipids & $21.69^{\mathrm{c}} \pm 0.21$ & $37.57^{\mathrm{b}} \pm 0.71$ & $38.13^{\mathrm{b}} \pm 1.39$ & $40.12^{\mathrm{ab}} \pm 1.75$ & $42.27^{\mathrm{a}} \pm 1.69$ \\
Crude protein $^{\text {Carbohydrates }^{\mathrm{b}}}$ & $21.52^{\mathrm{d}} \pm 0.19$ & $23.24^{\mathrm{c}} \pm 0.06$ & $24.42^{\mathrm{b}} \pm 0.11$ & $24.18^{\mathrm{b}} \pm 0.08$ & $25.38^{\mathrm{a}} \pm 0.10$ \\
\hline
\end{tabular}

${ }^{a}$ Values reported as means \pm SD of three replicate analyses $(n=3)$. Means followed by different letters in the same line are significantly different ( $\left.\mathrm{p}<0.05\right)$ by Tukey's test. ${ }^{\mathrm{b}} \mathrm{Carbohydrate}$ by difference - Nifext (Nitrogen-free extract).

Table 2. Fatty acid composition ( $\mathrm{mg} \mathrm{g}^{-1}$ total lipids) of chia, flax, and perilla seeds ${ }^{\mathrm{a}}$.

\begin{tabular}{|c|c|c|c|c|c|}
\hline Fatty Acids & Chia $^{\mathrm{a}}$ & Golden Flax $^{\mathrm{a}}$ & Brown Flax ${ }^{a}$ & White Perilla $^{a}$ & Brown Perilla $^{a}$ \\
\hline $16: 0$ & $58.57^{b c} \pm 0.36$ & $41.26^{\mathrm{d}} \pm 1.09$ & $61.16^{\mathrm{ab}} \pm 2.78$ & $63.33^{a} \pm 0.62$ & $56.97^{c} \pm 0.56$ \\
\hline 18:0 & $24.98^{\mathrm{b}} \pm 0.25$ & $26.68^{\mathrm{b}} \pm 0.91$ & $56.49^{a} \pm 2.69$ & $15.59^{c} \pm 0.22$ & $13.74^{\mathrm{c}} \pm 0.08$ \\
\hline $18: 1 n-9$ & $61.61^{\mathrm{e}} \pm 1.08$ & $154.02^{\mathrm{c}} \pm 3.97$ & $197.76^{\mathrm{a}} \pm 3.58$ & $115.82^{\mathrm{d}} \pm 0.91$ & $163.34^{\mathrm{b}} \pm 0.30$ \\
\hline $18: \ln -7$ & $5.91^{\mathrm{d}} \pm 0.06$ & $4.75^{\mathrm{c}} \pm 0.05$ & $6.45^{\mathrm{d}} \pm 0.16$ & $8.95^{\mathrm{a}} \pm 0.09$ & $6.70^{\mathrm{b}} \pm 0.07$ \\
\hline $18: 2 n-6(L A)$ & $174.73^{\mathrm{a}} \pm 1.70$ & $140.20^{\mathrm{b}} \pm 3.81$ & $127.49^{c} \pm 1.20$ & $139.04^{\mathrm{b}} \pm 0.01$ & $98.95^{\mathrm{d}} \pm 0.13$ \\
\hline $18: 3 n-6$ & $1.98^{a} \pm 0.09$ & $0.18^{\mathrm{b}} \pm 0.01$ & $0.17^{\mathrm{b}} \pm 0.01$ & $2.11^{\mathrm{a}} \pm 0.37$ & $1.85^{\mathrm{a}} \pm 0.07$ \\
\hline $20: 0$ & $\mathrm{Nd}$ & $1.73^{\mathrm{a}} \pm 0.03$ & $1.80^{\mathrm{a}} \pm 0.14$ & $0.97^{\mathrm{b}} \pm 0.01$ & $\mathrm{Nd}$ \\
\hline $18: 3 n-3$ (LNA) & $544.85^{\mathrm{a}} \pm 6.84$ & $483.49^{\mathrm{b}} \pm 8.12$ & $396.56^{c} \pm 9.44$ & $539.07^{\mathrm{a}} \pm 0.19$ & $531.44^{\mathrm{a}} \pm 0.53$ \\
\hline $20: 1 n-9$ & $\mathrm{Nd}$ & $1.26^{a} \pm 0.04$ & $0.99 b \pm 0.05$ & $1.03^{\mathrm{b}} \pm 0.04$ & $\mathrm{Nd}$ \\
\hline SFA & $83.55^{\mathrm{b}} \pm 0.44$ & $71.51^{\mathrm{c}} \pm 2.08$ & $123.69^{\mathrm{a}} \pm 5.50$ & $79.89^{\mathrm{b}} \pm 0.66$ & $70.71^{\mathrm{c}} \pm 0.57$ \\
\hline MUFA & $67.52^{\mathrm{e}} \pm 1.08$ & $160.85^{\mathrm{c}} \pm 4.04$ & $207.16^{\mathrm{a}} \pm 3.77$ & $125.80^{\mathrm{d}} \pm 0.91$ & $170.04^{\mathrm{b}} \pm 0.31$ \\
\hline PUFA & $719.58^{a} \pm 7.05$ & $624.03^{\mathrm{c}} \pm 11.45$ & $524.36^{\mathrm{d}} \pm 10.65$ & $680.22^{\mathrm{b}} \pm 0.42$ & $632.24^{c} \pm 0.55$ \\
\hline$n-6$ & $176.71^{\mathrm{a}} \pm 1.70$ & $140.54^{\mathrm{b}} \pm 3.81$ & $127.80^{c} \pm 1.21$ & $141.15^{\mathrm{b}} \pm 0.37$ & $100.8^{\mathrm{d}} \pm 0.15$ \\
\hline$n-3$ & $544.85^{\mathrm{a}} \pm 6.84$ & $483.49^{\mathrm{b}} \pm 8.12$ & $396.56^{c} \pm 9.44$ & $539.07^{\mathrm{a}} \pm 0.19$ & $531.44^{\mathrm{a}} \pm 0.53$ \\
\hline$n-6 / n-3$ & $0.32^{\mathrm{a}} \pm 0.00$ & $0.25^{\mathrm{b}} \pm 0.00$ & $0.28^{\mathrm{a}} \pm 0.00$ & $0.26^{c} \pm 0.00$ & $0.19^{\mathrm{d}} \pm 0.00$ \\
\hline
\end{tabular}

${ }^{a}$ Values reported as means \pm SD of three replicate analyses $(n=3)$. Means followed by different letters in the same line are significantly different ( $\left.\mathrm{p}<0.05\right)$ by Tukey's test. nd = not detected, LA = linoleic acid, LNA = alpha linolenic acid, SFA = total saturated fatty acids, MUFA = total monounsaturated fatty acids, PUFA = total polyunsaturated fatty acids, $n-6=$ total omega- $6, n-3=$ total omega- 3 fatty acids. 
linolenic acid (LNA, 18:3 n-3). It is the predominant fatty acid in seeds, ranging from 396.56 to $544.85 \mathrm{mg} \mathrm{g}^{-1}$ representing from $46.72 \%$ to $62.44 \%$ of the total fatty acids in the lipid fraction. Chia and white and brown perilla seeds showed the highest concentrations of LNA, 544.85, 539.07, and $531.44 \mathrm{mg} \mathrm{g}^{-1}$, respectively, with no statistically difference between these groups. In a study on perilla seeds during the growth cycle, the LNA value ranged from 52.00 to $55.50 \%$ of the total fatty acids, indicating that the lipid composition of perilla seed depends on the plant maturity stage (PEIRETTI, 2011).

Evaluating the effect of different growing areas on the fatty acid composition of chia seed, Ayerza (2010) obtained LNA contents ranging from 61.06 to $66.75 \%$, which differ from the values found in this study. Differences in fatty acid composition in chia seeds can be attributed to differences in environmental conditions such as temperature, light, soil type, nutrient availability (PEIRETTI; GAI, 2009), location (AYERZA, 2010), and the ecosystem where they are grown (AYERZA; COATES, 2011).

The oilseeds investigated are also good sources of oleic acid (18:1n-9) and linoleic acid LA (18:2n-6). Brown flax and chia seeds showed the most significant amounts of oleic and linolenic acids, 197.76 and $174.73 \mathrm{mg} \mathrm{g}^{-1}$, respectively, differing significantly $(\mathrm{p}<0.05)$ from the other samples.

All seeds evaluated showed high concentrations of polyunsaturated fatty acids (PUFA), with results for brown flax and chia ranging from 524.36 to $719.58 \mathrm{mg} \mathrm{g}^{-1}$, respectively, representing from $60 \%$ to $80 \%$ of total acids found in the lipid fraction. White perilla and golden flax seeds showed significant difference regarding PUFA concentrations (Table 2).

The $n-6 / n-3$ ratio of the evaluated seeds ranged from 0.19 in brown perilla to 0.32 in chia. These results were similar to those found by Ciftci, Roman and Rudzinska (2012) for chia, perilla, and flax seeds, while Ayerza (2010) found lower rates for chia (from 0.23 to 0.32 ) than those reported in this study. The ratios obtained for perilla seeds were close to 0.23 (KIM; PARK; CHOUNG, 2007) and 0.25 (ECKERT; FRANKE; NOLDNER, 2010), values found in other studies. Alpha-linolenic acid (omega-3) and linoleic acid (omega-6) are considered strictly essential because they cannot be synthesized in the human body (AGUIAR et al., 2011) and, therefore, must be obtained through the diet. The beneficial health effects of omega- 3 fatty acids have been extended to include benefits related to cancer, inflammatory bowel disease, rheumatoid arthritis, psoriasis, and mental health (SIMOPOULOS, 2011), with also a positive effect in the treatment of depression and schizophrenia (PEET; STOKES, 2005; SCHRAM et al., 2007). The $n-6 / n-3$ ratios obtained for all seeds were consistent with the recommended ratio of 1:1 for a healthy balanced nutrition (SIMOPOULOS, 2011).

The Institute of Medicine of the National Academies (2005) recommends a daily intake of LNA of $1.6 \mathrm{~g} /$ day for men and $1.1 \mathrm{~g} /$ day for women. An individual would need to consume approximately $8 \mathrm{~g}$ of the perilla seeds (white or brown) or $15 \mathrm{~g}$ of the evaluated chia seeds per day to reach the recommended LNA daily intake (Table 2).

\subsection{Antioxidant capacity}

Table 3 shows the TEAC results for the five seeds studied. The DPPH' and FRAP assays of all seeds showed significant differences $(\mathrm{p}<0.05)$. In the $\mathrm{DPPH}{ }^{*}$ assay, the highest value was found for brown perilla $(2.54 \pm 0.07)$, and the lowest value for the golden flax $(1.16 \pm 0.04)$. A similar pattern was found in the FRAP assay, in which brown perilla had the highest $(5.24 \pm 0.09)$ and golden flax the lowest $(0.33 \pm 0.01)$ values

For the $\mathrm{ABTS}^{\bullet+}$ assay, the highest value was also found in brown perilla seed $(4.06 \pm 0.07)$.

These different assay results found in this study show the importance of using two or more radical scavenging capacity assays to investigate heterogeneous samples since each assay involves different chemical mechanism(s) and may reflect different aspect(s) of the antioxidant properties (SERPEN; GÖKMEN; FOGLIANO, 2012a).

Müller-Waldeck et al. (2010) determined antioxidant capacity of five varieties of Perilla frutescens L. using the ABTS ${ }^{\bullet+}$

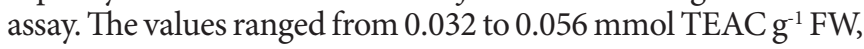
which are lower than the results found in the present study for white and brown perilla, $3.32 \pm 0.05$ and $4.06 \pm 0.07$, respectively. This variation may have been due to the dependence of the sample composition on factors such as climate conditions and geographic location (MEZADRI et al., 2008; VASCO; RUALES; KAMAL-ELDIN, 2008).

A factor that limits the comparison of studies is the extraction procedure used since it is a critical process for some matrices, particularly when there may be insoluble components with antioxidant capacity, which lead to underestimated TEAC values in some cases (SERPEN et al., 2007; SERPEN; GÖKMEN; FOGLIANO, 2012a).

Using the QUENCHER procedure for the ABTS ${ }^{\bullet+}$ assay, Serpen et al. (2008) determined the antioxidant capacity of some seeds such as rice $\left(0.12 \mathrm{mmol}\right.$ TEAC $\left.\mathrm{g}^{-1}\right)$, wheat $\left(0.04 \mathrm{mmol} \mathrm{TEAC}^{-1}\right)$, and maize $\left(0.010 \mathrm{mmol} \mathrm{TEAC}^{-1}\right)$. These results are lower than those found for all seeds in the present study for the $\mathrm{ABTS}^{\bullet+}$ assay.

Table 3. Antioxidant capacity $\left(\mathrm{ABTS}^{*+}{ }^{-\mathrm{DPPH}^{*}}\right.$ and FRAP) of chia, flax, and perilla seeds ${ }^{\mathrm{a}}$.

\begin{tabular}{|c|c|c|c|c|c|}
\hline $\begin{array}{c}\text { Mmol } \\
\text { TEAC g-1 }\end{array}$ & Chia & Golden flax & Brown flax & White perilla & Brown Perilla \\
\hline $\mathrm{ABTS}^{+}$ & $2.56^{\mathrm{a}} \pm 0.03$ & $3.38^{b} \pm 0.09$ & $3.70^{c} \pm 0.09$ & $3.32^{b} \pm 0.05$ & $4.06^{\mathrm{d}} \pm 0.07$ \\
\hline DPPH• & $1.72^{\mathrm{a}} \pm 0.09$ & $1.16^{\mathrm{b}} \pm 0.04$ & $1.56^{\mathrm{c}} \pm 0.01$ & $2.38^{\mathrm{e}} \pm 0.00$ & $2.54^{\mathrm{d}} \pm 0.07$ \\
\hline FRAP & $2.86^{\mathrm{a}} \pm 0.10$ & $0.33^{\mathrm{b}} \pm 0.01$ & $0.76^{c} \pm 0.01$ & $4.01^{\mathrm{e}} \pm 0.29$ & $5.24^{\mathrm{d}} \pm 0.09$ \\
\hline
\end{tabular}

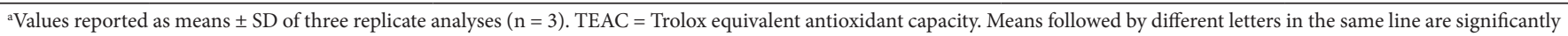
different $(\mathrm{p}<0.05)$ by Tukey's test. 


\subsection{PCA analysis}

The data matrix of the variables analyzed was performed for two fatty acids, LNA and LA; five sum values, SFA, MUFA, PUFA, omega-6, and omega-3 (Table 4); and three antioxidant assays (Table 5) for five seeds. Principal Components Analysis (PCA) was applied in order to reduce the number of descriptors associated with the data set, which explains the maximum amount of variability of the data. The PCA was applied because oilseeds are a very complex mixture (WU; RODGERS; MARSHALL, 2004).

Tables 4 and 5 show that the eigenvalues and more than $85 \%$ of the variance in the original data set are explained by both analyses. Thus, three components were retained for the principal component analysis of fatty acid and two for antioxidant analysis.

The first component (PC1) for fatty acids and sums explained $74.63 \%$ of the data set total variance; the loadings indicated high contributions from LNA (0.1813) (Table 4), n-3 (0.1824), and PUFA (0.1824). The second component (PC2) explained $21.92 \%$ of the total variance, and the third component (PC3) explained 3.36\%. LA (0.5200) had a positive contribution to PC2 and SFA (0.3394) to PC3. The total data set variance for fatty acid analysis was $99.91 \%$.

Figure 1 shows the principal component analysis results (loadings PC1xPC2 (a), PC1xPC3 (b and PC1xPC3 (b) and score plot of PC1xPC2 (c) and PC1xPC3 (d)) of fatty acids for seed samples. Analyzing Figures $1 \mathrm{c}$ and $1 \mathrm{~d}$, it can be observed that six groups were formed. In Figure 1c, the groups formed were brown flax (B Flax (1)); brown perilla, golden flax, and white perilla (B Perilla, G Flax and W Perilla, respectively (2)); Chia (3); and in Figure 1d, B Flax (4); B Perilla, W Perilla, and Chia (5); G Flax (6). Analyzing Figures 1a and 1c, it can be seen that the variable responsible for the formation of group 1 was MUFA, with the highest value; for group 2, it was the n-3 and LNA sums, with intermediate values; for group 3, it was LA, showing higher levels of this fatty acid. The correlation between Figures $1 \mathrm{~b}$ and $1 \mathrm{~d}$ shows that the variable SFA contributed to group 4, with a lower content; for group 5, it was the LNA and n-3 sums, which had the greatest amounts; and group 6 had the highest LA content.

In the antioxidant analyses, two selected components explained about $87.83 \%$ of the total variance, PC1 (54.88\%), and PC2 (32.94\%). Variable FRAP had a high contribution to PC1, with 0.4951 (Table 4). PC2 loadings indicate that it had high contributions from ABTS A $^{*+9080)}$.

Figure 2 shows PCA results (loadings (a) and scores (b)) of the antioxidant analyses of the seed samples. According to Figure $2 b$, we can observe that five groups were formed, one for each seed type. Variable $\mathrm{DPPH}^{\bullet}$ was responsible for the separation of G Flax with a value lower than B Flax, which

Table 4. Eigen analysis of the correlation matrix loadings of the significant principal components (PCs) for fatty acids.

\begin{tabular}{cccc}
\hline & PC1 & PC2 & PC3 \\
\hline Eigenvalue & 5.224383 & 1.534058 & 0.235437 \\
\% Total Variance & 74.63405 & 21.91512 & 3.36338 \\
\% Cumulative & 74.6340 & 96.5492 & 99.9125 \\
& & & 0.233389 \\
LA & 0.028072 & $\mathbf{0 . 5 2 0 0 0 6}$ & 0.132902 \\
LNA & $\mathbf{0 . 1 8 2 4 2 2 ^ { \mathrm { a } }}$ & 0.010126 & $\mathbf{0 . 3 3 9 3 6 9}$ \\
SFA & 0.134369 & 0.141742 & 0.023779 \\
MUFA & 0.136629 & 0.180576 & 0.020376 \\
PUFA & $\mathbf{0 . 1 8 1 3 5 4}$ & 0.030679 & 0.117283 \\
n-6 & 0.154733 & 0.106744 & 0.132902 \\
n-3 & $\mathbf{0 . 1 8 2 4 2 2}$ & 0.010126 & \\
\hline
\end{tabular}

${ }^{a}$ The most significant loadings are in bold. LA = linoleic acid, LNA = alpha-linolenic acid, SFA = total saturated fatty acids, MUFA = total monounsaturated fatty acids, PUFA = total polyunsaturated fatty acids, $n-6=$ total omega- $6, n-3=$ total omega- 3 fatty acids.

Table 5. Eigenanalysis of the correlation matrix loadings of the significant principal components (PCs) for antioxidant analyses.

\begin{tabular}{|c|c|c|c|}
\hline & PC1 & PC2 & PC3 \\
\hline Eigenvalue & 1.646503 & 0.988265 & 0.365231 \\
\hline$\%$ Total Variance & 54.88345 & 32.94218 & 12.17438 \\
\hline \% Cumulative & 54.8834 & 87.8256 & 100.0000 \\
\hline ABTS $^{+}$ & 0.053889 & 0.908011 & 0.038100 \\
\hline DPPH• & 0.451018 & 0.091315 & 0.457667 \\
\hline FRAP & $0.495093^{\mathrm{a}}$ & 0.000674 & 0.504233 \\
\hline
\end{tabular}

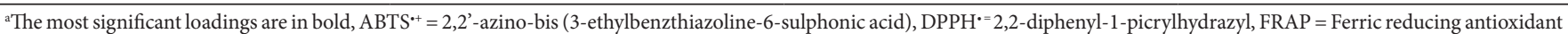
power. 


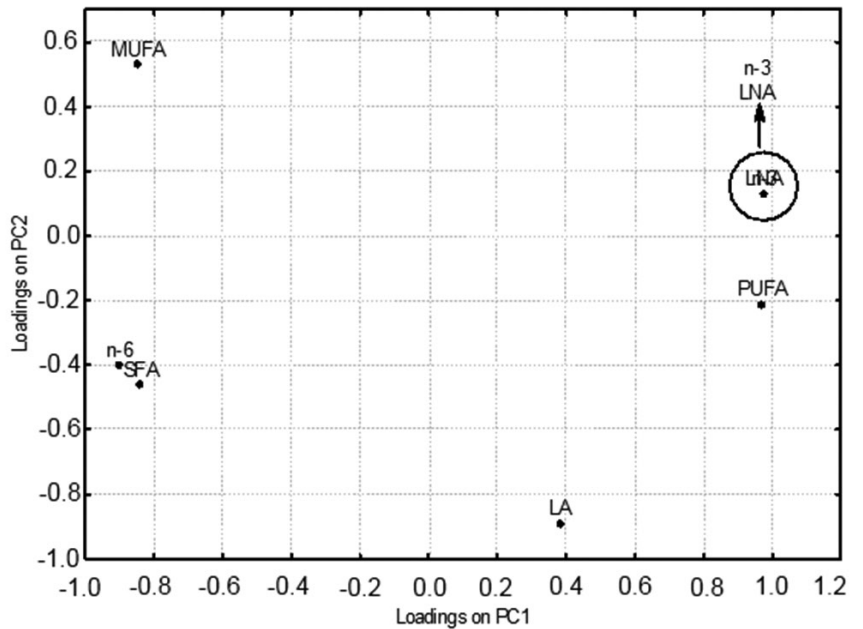

(a)

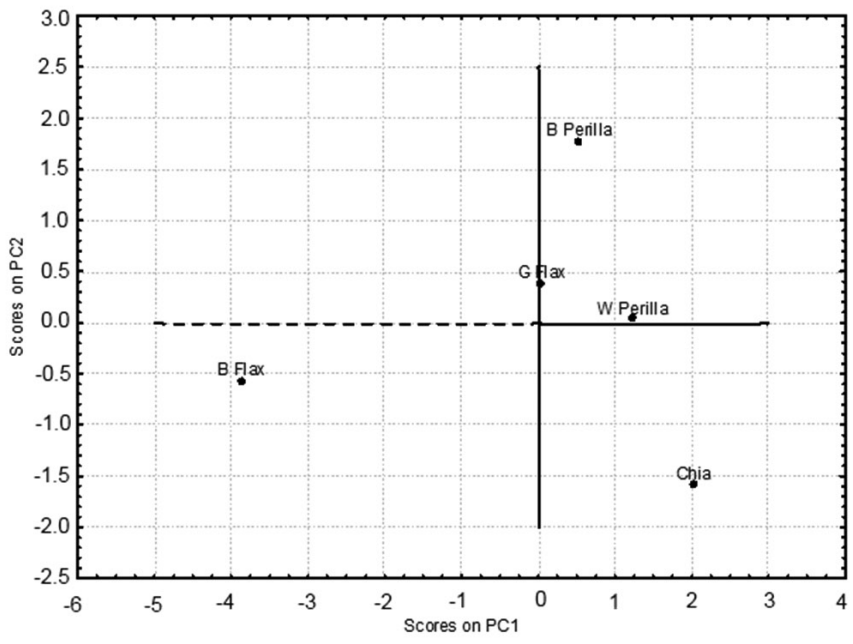

(c)

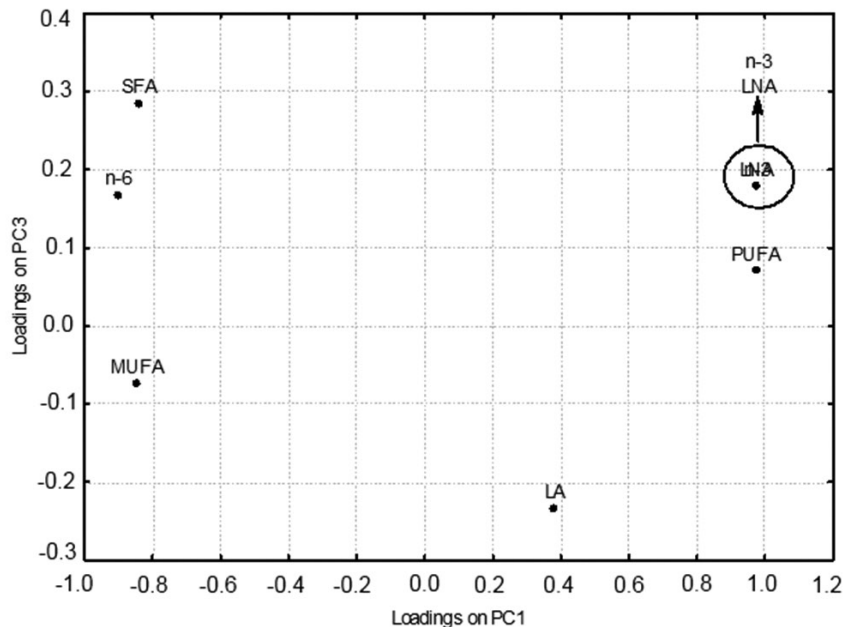

(b)

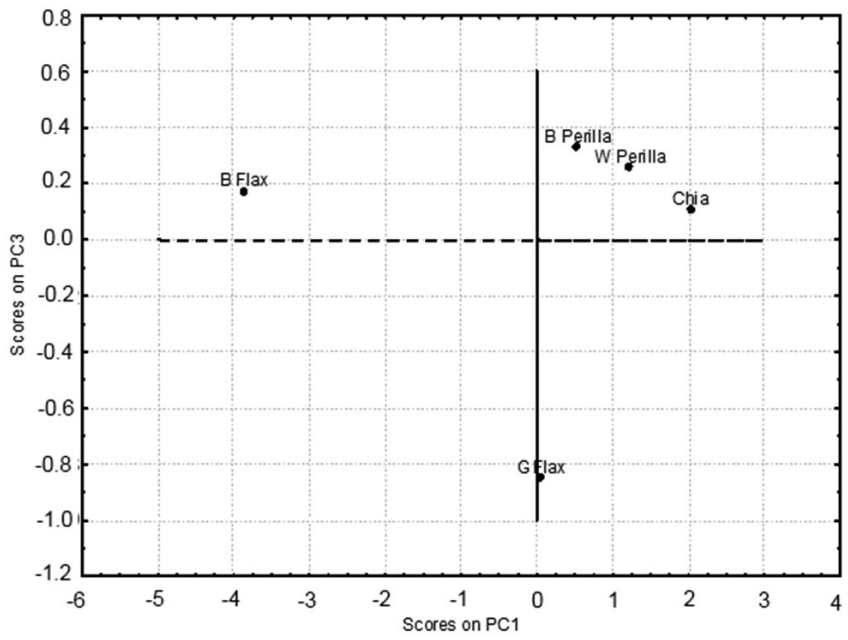

(d)

Figure 1. Loading plot of PC1xPC2 (a) and PC1xPC3 (b) and score plot of PC1xPC2 (c) and PC1xPC3 (d) for fatty acids in chia, brown flax (Flax B), golden flax (Flax G), and white perilla (Perilla W) and brown perilla (Perilla B) seeds.
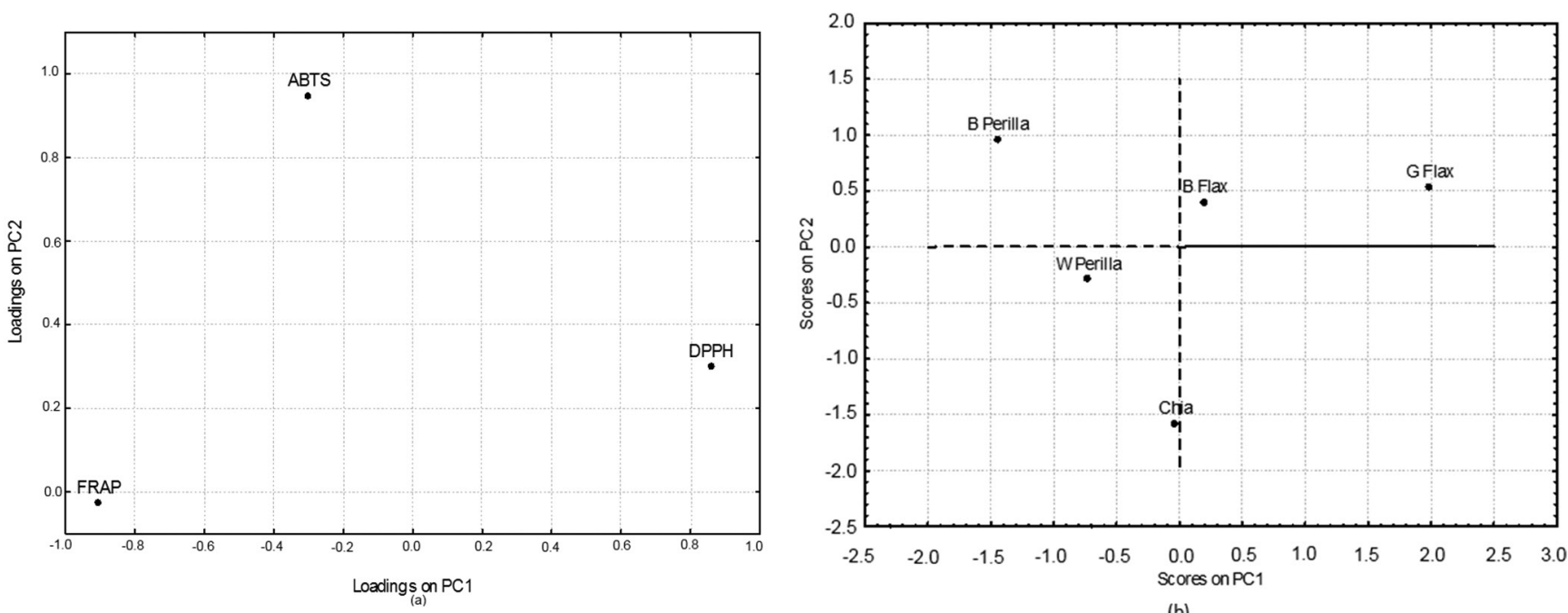

(b)

Figure 2. Loadings plot (a) and scores plot (b) of PC1xPC2 for antioxidant analyses of chia, brown flax (B Flax), golden flax (G Flax), and white perilla (W Perilla) and brown perilla (B Perilla) seeds. 
presented low values for $\mathrm{DPPH} \mathrm{H}^{\bullet}$ but high values for $\mathrm{ABTS}^{\bullet+}$. B Perilla had the highest values for ABTS ${ }^{*+}$ and FRAP, followed by $\mathrm{W}$ perilla. Chia showed intermediate values in all analyses.

\section{Conclusion}

This study revealed that the seeds evaluated, chia, golden flax, brown flax, white perilla, and brown perilla are excellent sources of alpha-linolenic acid (LNA), which is a precursor of long chain PUFA metabolically synthesized in the human body. These seeds can be used in natura as flours and/or oils to enrich food products with LNA and thus change the n-6-to- $n-3$ ratio in the diet. Among the flax and perilla species, the gold and white species had higher levels of omega- 3 and -6 , while both brown flax and perilla seeds showed higher antioxidant capacity and chia showed a higher content of fatty acids and intermediate antioxidant capacity. The PCA showed that the eigenanalysis of the correlation matrix loadings of the three and two significant PCs for fatty acids and antioxidant capacity, respectively, explained more than $85 \%$ of data variation in both analyses.

\section{Acknowledgements}

This study was supported by Coordenadoria de Aperfeiçoamento de Pessoal de Nível Superior (CAPES).

\section{References}

AGUIAR, A. C. et al. Effect of flaxseed oil in diet on fatty acid composition in the liver of Nile Tilapia (Oreochromis niloticus). Archivos Latinoamericanos de Nutrición, v. 57, p. 273-277, 2007. Pmid:18271406.

AGUIAR, A. C. et al. Quantification of essential fatty acids in the heads of nile tilapia (Oreochromis niloticus) fed with linseed oil. Journal of the Brazilian Chemical Society, v. 22, p. 643-647, 2011. http:// dx.doi.org/10.1590/S0103-50532011000400005

ÁLVAREZ-CHÁVEZ, L. M. et al. Chemical characterization of the lipid faction of Mexican chia seed (Salvia hispânica L.). International Journal of Food Properties, v. 11, p. 687-697, 2008. http://dx.doi. org/10.1080/10942910701622656

ANJO, D. F. C. Alimentos funcionais em angiologia e cirurgia vascular. Jornal Vascular Brasileiro, v. 2, p. 145-154, 2004.

ASIF, M. Health effects of omega-3, 6, 9 fatty acids: Perilla frutescens is a good example of plant oils. Oriental Pharmacy and Experimental Medicine, v. 11, p. 51-59, 2011. PMid:21909287 PMCid:PMC3167467. http://dx.doi.org/10.1007/s13596-0110002-X

ASSOCIATION OF OFFICIAL ANALYTICAL CHEMISTS - AOAC. Official methods of analysis of AOAC international. 16 th ed. AOAC; 1998.

AYERZA, R. Effects of seed color and growing locations on fatty acid content and composition of two chia (Salvia hispanica L.) genotypes. Journal of the American Oil Chemists Society, v. 87, p. 1161-1165, 2010. http://dx.doi.org/10.1007/s11746-010-1597-7

AYERZA, R.; COATES, W. Protein content, oil content and fatty acid profiles as potential criteria to determine the origin of commercially grown chia (Salvia hispanica L.). Industrial Crops and Products, v. 34, n. 2, p. 1366-1371, 2011. http://dx.doi.org/10.1016/j. indcrop.2010.12.007

BENZIE, I. F. F.; STRAIN, J. J. The Ferric Reducing Ability of Plasma (FRAP) as a Measure of "Antioxidant Power": The FRAP Assay.
Analytical Biochemistry, v. 239, p. 70-76, 1996. PMid:8660627. http://dx.doi.org/10.1006/abio.1996.0292

BLIGH, E. G.; DYER, W. J. A rapid method of total lipid extraction and purification. Canadian Biochemistry Physiology, v. 37, p. 911917, 1959. http://dx.doi.org/10.1139/o59-099

BRAND-WILLIAMS, W.; CUVELIER, M. E.; BERSET, C. Use of a free radical method to evaluate antioxidant activity. LWT - Food Science and Technology, v. 28, p. 25-30, 1995.

CIFTCI, O. N.; ROMAN, P.; RUDZINSKA, M. Lipid components of flax, perilla, and chia seeds. European Journal of Lipid Science and Technology, v. 114, p. 794-800, 2012. http://dx.doi.org/10.1002/ ejlt.201100207

COATES, W.; AYERZA, R. Production potential of chia in Northwestern Argentina. Industrial Crops and Products, v. 5, p. 229-233, 1996. http://dx.doi.org/10.1016/0926-6690(96)89454-4

DUCATTI, T. et al. Chemical Composition and Fatty Acid Profile in Crossbred (Bos taurus vs. Bos indicus) Young Bulls Finished in a Feedlot. Asian-Australasian Journal of Animal Sciences, v. 22, p. 433-439, 2009.

ECKERT, G. P.; FRANKE, C.; NOLDNER, M. Plant derived omega-3-fatty acids protect mitochondrial function in the brain. Pharmacological Research, v. 61, p. 234-241, 2010. PMid:20079842. http://dx.doi.org/10.1016/j.phrs.2010.01.005

GALVÃO, E. L. et al. Avaliação do potencial antioxidante e extração subcrítica do óleo de linhaça. Ciência e Tecnologia de Alimentos, v. 28, p. 551-557, 2008. http://dx.doi.org/10.1590/S010120612008000300008

GHULE, A. E.; JADHAV, S. S.; BODHANKAR, S. L. Effect of ethanolic extract of seeds of Linum usitatissimum (Linn.) in hyperglicaemia associated ROS production in PBMNCs and pancreatic tissue of alloxan induced diabetic rats. Asian Pacific Journal of Tropical Biomedicine, p. 405-410, 2012.

HARTMAN, L.; LAGO, R. C. A. Rapid determination of fatty acid methyl esthers from lipids. Laboratory Practice, v. 22, p. 475-477, 1973. PMid:4727126.

HERCI, W. et al. Determination of phenolic and other polar compounds in flaxseed oil using liquid chromatography coupled with time-offlight mass spectrometry. Food Chemistry, v. 126, p. 332-338, 2011. http://dx.doi.org/10.1016/j.foodchem.2010.10.070

INSTITUTE OF MEDICINE. Dietary Reference Intakes for Energy, Carbohydrate, Fiber, Fat, Fatty Acids, Cholesterol, Protein, and Amino Acids (Macronutrients). Washington: National Academy Press, 2005.

IXTAINA, Y. V.; NOLASCO, S. M.; TOMÁS, M. C. Physical properties of chia (Salvia Hispanica L.) seeds. Industrial Crops and Product, v. 28, p. 286-293, 2008. http://dx.doi.org/10.1016/j. indcrop.2008.03.009

JOSEPH, J. D.; ACKMAN, R. G. Capillary column gas-chromatographic method for analysis of encapsulated fish oils and fish oil ethylesters - Collaborative study. Journal of AOAC International, v. 75, p. 488-506, 1992.

KASOTE, D. M.; BADHE, Y. S.; HEDGE, M. V. Effect of mechanical press oil extraction processing on quality of linseed oil. Industrial Crops and Products, v. 42, p. 10-13, 2013. http://dx.doi. org/10.1016/j.indcrop.2012.05.015

KENDALL, M. et al. Nutritional methodologies and their use in inter-disciplinary antioxidant research. Food Chemistry, v. 108, p. 425-438, 2008. http://dx.doi.org/10.1016/j.foodchem.2007.10.076

KIM, K. S.; PARK S. H.; CHOUNG, M. G. Nondestructive determination of oil content and fatty acid composition in perilla seeds by near-infrared spectroscopy. Journal of Agricultural and Food Chemistry, v. 55, p. 1679-1685, 2007. http://dx.doi. org/10.1021/jf0631070 
KUROWSKA, E. M. et al. Bioavailability of omega-3essential fatty acidsfrom perilla seed oil. Prostaglandins, Leukotrienes and Essential Fatty Acids, v. 68, p. 207-212, 2003. http://dx.doi. org/10.1016/S0952-3278(02)00271-5

MARTIN, C. A. et al. Optimization of the selectivity of a cyanopropyl stationary phase for the gas chromatographic analysis of trans fatty acids. Journal of Chromatographi A, v. 1194, p. 111-117, 2008. PMid:18468609. http://dx.doi.org/10.1016/j.chroma.2008.04.033

MATSUSHITA, M. et al. Fatty acid profile of milk from Saanen goats fed a diet enriched with three vegetable oils. Small Ruminant Research, v. 72, p. 127-132, 2007. http://dx.doi.org/10.1016/j. smallrumres.2006.09.003

MENG, L. et al. Antioxidant activities of polyphenols extracted from Perilla frutescens Varieties. Molecules, v. 14, p. 133-140, 2009. PMid:19127243. http://dx.doi.org/10.3390/molecules14010133

MEZADRI, T. et al. Antioxidant compounds and antioxidant activity in acerola (Malpighia emarginata DC.) fruits and derivatives. Journal of Food Composition and Analysis, v. 21, p. 282-290, 2008. http:// dx.doi.org/10.1016/j.jfca.2008.02.002

MÜLLER-WALDECK, F. et al. Determination of toxic perilla ketone, secondary plant metabolites and antioxidative capacity in fivePerilla frutescens L. varieties. Food and Chemical Toxicology, v. 48, p. 264-270, 2010. PMid:19833165. http://dx.doi.org/10.1016/j. fct.2009.10.009

MUÑOZ, L. A. et al. Chia seeds: Microstructure, mucilage extraction and hydration. Journal of Food Engineering, v. 108, p. 216-224, 2012. http://dx.doi.org/10.1016/j.jfoodeng.2011.06.037

NIVA, M.; MÄKELÄ, J. Sócio-demografics, health efforts, notions of technology and acceptability of health-promoting foods. International Journal of Consumer Studies, v. 31, p. 34-45, 2007. http://dx.doi.org/10.1111/j.1470-6431.2005.00482.x

OLIVOS-LUGO, B. L.; VALDIVIA-LÓPEZ, M. A.; TECANTE, A. Thermal and physicochemical properties and nutritional value of the protein fraction of Mexican chia seed (Salvia hispanica L.). Food Science and Technology International, v. 16, p. 89-96, 2010. PMid:21339125. http://dx.doi.org/10.1177/1082013209353087

OMAR, K. A. et al. Stabilizing flaxseed oil with individual antioxidants and their mixture. European Journal of Lipid Science and Technology, v. 112, p. 1003-1011, 2010. http://dx.doi.org/10.1002/ ejlt.200900264

PEET, M.; STOKES, C. Omega- 3 fatty acids in the treatment of psychiatric disorders. Drugs, v. 65, p. 1051-1059, 2005. PMid:15907142. http://dx.doi.org/10.2165/00003495-20056508000002

PEIRETTI, P. G. Fatty acid content and chemical composition of vegetative parts of perilla (Perilla frutescens L.) after different growth lengths. Research Journal of Medicinal Plant, v. 5, p. 72-78, 2011. http://dx.doi.org/10.3923/rjmp.2011.72.78

PEIRETTI, P. G.; GAI, F. Fatty acid and nutritive quality of chia (Salvia hispanica L.) seeds and plant during growth. Animal Feed Science and Technology, v. 148, 267-275, 2009. http://dx.doi.org/10.1016/j. anifeedsci.2008.04.006

PEIRETTI, P. G. et al. Effects of perilla (Perilla frutescens L.) seeds supplementation on performance, carcass characteristics, meat quality and fatty acid composition of rabbits. Livestock Science, v. 138, p. 118-124, 2011. http://dx.doi.org/10.1016/j. livsci.2010.12.007

RE, R. et al. Antioxidant activity applying an improved ABTS radical cation decolorization assay. Free Radical Biology \& Medicine, v. 26, p. 1231-1237, 1999. http://dx.doi.org/10.1016/S08915849(98)00315-3
REYES-CAUDILLO, E.; TECANTE, A.; VALDIVIA-LÓPEZ, M. A. Dietary fibre content and antioxidant activity of phenolic compounds present in Mexican chia (Salvia hispanica L.) seeds. Food Chemistry, v. 107, p. 656-663, 2008. http://dx.doi. org/10.1016/j.foodchem.2007.08.062

RUBILAR, M. et al. Flaxseed as a source of functional ingredients. Journal of Soil Science and Plant Nutrition, v. 10, p. 373-377, 2010. http://dx.doi.org/10.4067/S0718-95162010000100010

RUIZ, M. R. et al. Proximate chemical composition and fatty acid profiles of Longissimus thoracis from pasture fed LHRH immunocastrated, castrated and intact Bos indicus bulls. South African Journal of Animal Science, v. 35, p. 13-18, 2005.

SCHRAM, L. B. et al. Food matrices affect the bioavailability of (n-3) polyunsaturated fatty acids in a single meal study in humans. Food Research International, v. 40, p. 1062-1068, 2007. http://dx.doi. org/10.1016/j.foodres.2007.06.005

SERPEN, A. et al. A New Procedure To Measure the Antioxidant Capacity of Insoluble Food Components. Journal Agriculture and Food Chemistry, v. 55, p. 7676-7681, 2007. PMid:17708649. http:// dx.doi.org/10.1021/jf071291z

SERPEN, A.; GÖKMEN, V.; FOGLIANO, V. Solvent effects on total antioxidant capacity of foods measured by direct QUENCHER procedure. Journal of Food Composition and Analysis, v. 26, p. 52-57, 2012a. http://dx.doi.org/10.1016/j.jfca.2012.02.005

SERPEN, A.; GÖKMEN, V.; FOGLIANO, V. Total antioxidant capacities of raw and cooked meats. Meat Science, v. 90, p. 60-65, $2012 \mathrm{~b}$. PMid:21684086. http://dx.doi.org/10.1016/j.meatsci.2011.05.027

SERPEN, A. et al. Direct measurement of the total antioxidant capacity of cereal products. Journal of Cereal Science, v. 48 , p. 816-820, 2008. http://dx.doi.org/10.1016/j.jcs.2008.06.002

SIMOPOULOS, A. P. Evolutionary aspects of diet: the omega-6/ omega-3 ratio and the brain. Molecular Neurobiology, v. 44, p. 203-215, 2011. PMid:21279554. http://dx.doi.org/10.1007/ S12035-010-8162-0

TONIAL, I. B. et al. Optimization of flaxseed oil feeding time length in adult Nile tilapia (Oreochromis niloticus) as a function of muscle omega-3 fatty acids composition. Aquaculture Nutrition, v. 15 , p. 564-568, 2009. http://dx.doi.org/10.1111/j.13652095.2008.00623.x

VASCO, C.; RUALES, J.; KAMAL-ELDIN, A. Total phenolic compounds and antioxidant capacities of major fruits from Ecuador. Food Chemistry, v. 111, p. 816-823, 2008. http://dx.doi. org/10.1016/j.foodchem.2008.04.054

VÁZQUEZ-OVANDO, A. et al. Physicochemical properties of a fibrous fraction from chia (Salvia hispanica L.), LWT. Food Science and Technology, v. 42, p. 168-173, 2009.

VISENTAINER, J. V. Aspectos analíticos da resposta do detector de ionização em chama para ésteres de ácidos graxos em biodisel e alimentos. Química Nova, v. 35, p. 274-279, 2012. http://dx.doi. org/10.1590/S0100-40422012000200008

WU, Z. G.; RODGERS, R. P.; MARSHALL, A. G. Characterization of vegetable oils: Detailed compositional fingerprints derived from electrospray ionization Fourier transform ion cyclotron resonance mass spectrometry. Journal of Agricultural and Food Chemistry, v. 52, p. 5322-5328, 2004. PMid:15315364. http://dx.doi. org/10.1021/jf049596q

ŽEKONIS, G. et al. Effect of Perilla frutescens aqueous extract on free radical production by human neutrophil leukocytes. Medicina Kaunas, v. 44, p. 699-705, 2008. 